\title{
Blurring Boundaries: Facebook Groups as Digital Teachers' Lounges for ELT Professionals ${ }^{1}$
}

\author{
Ali Fuad SELVi ${ }^{2}$ \\ Submitted by: 03.01 .2021 \\ Accepted by: 14.02 .2021 \\ Article Type: Research Article
}

\begin{abstract}
Recent years have witnessed a rapid and widespread proliferation of information technologies and internet-based applications and platforms, commonly referred to as social media, which powerfully infused into almost every aspect of our lives, including teaching, teacher education and professional development. Departing from this premise, the current study provided a systematic analysis of Facebook groups serving as networks of professional development for ELT professionals in Turkey. The two-level analysis adopted lurking as a data collection strategy and thematic content analysis as an analytical lens. The macro analysis generated a corpus of these groups ( $n=55$ ) and investigated how they positioned themselves by analyzing their group size, titles, descriptions and group cover photos. The micro analysis focused on two of the most influential groups and shed light on the actual activities in the form of posts occurring in these groups in June 2020 ( $n=189, n=1,063$, respectively, and a total of $n=1,252)$. The two-level analysis indicated that these groups could be defined as utilitarian (predominantly requesting information and/or providing supplementary docs, instructional videos, revision tests) and socially-oriented (social exchanges with like-minded colleagues). Thus, it could be argued that these groups serve primarily as professionally-focused spaces of socialization, like a digital teachers' lounge where teachers (coming from the same area of specialty) interact with each other, socialize but also discuss work, give or ask for help on a range of professional, administrative, logistical and administrative matters.
\end{abstract}

Keywords: Professional Development, Social Media, ELT Professionals, Facebook

Atıf: Selvi, A. F. (2020). Blurring boundaries: Facebook groups as digital teachers' lounges for ELT professionals. Anadolu Üniversitesi Sosyal Bilimler Dergisi, 21(1), 251-272.

\footnotetext{
${ }^{1}$ Due to the nature of the study, informed consent or ethics committee approval was not required.

${ }^{2}$ Middle East Technical University Education and Humanities Teaching English as a Foreign Language Program, selvi@metu.edu.tr, ORCID: 00000002-1122-9770
} 


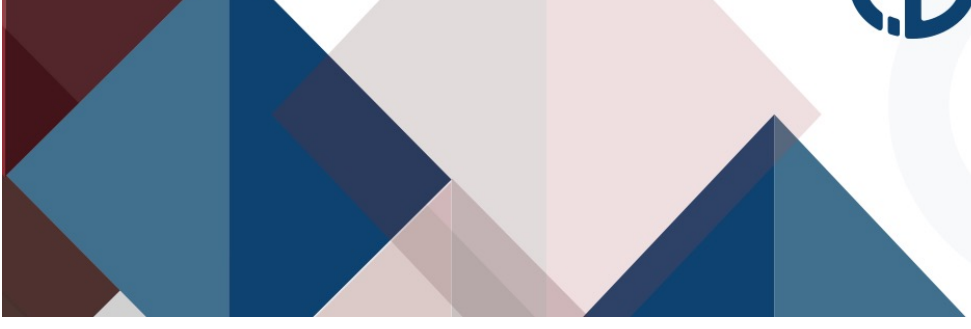

\title{
AÜSBD
}

Anadolu Üniversitesi Sosyal Bilimler Dergisi

Anadolu University Journal of Social Sciences

\section{Bulanıklaşan Sınırlar: İngilizce Öğretmenleri İçin Sanal Zümre Odaları Olarak Facebook Grupları}

\author{
Ali Fuad SELVi ${ }^{3}$
}

\author{
Başvuru Tarihi: 03.01.2021 Kabul Tarihi: 14.02.2021 Makale Türü: Araştırma Makalesi
}

\section{Öz}

Son yıllarda, sosyal medya olarak adlandirılan bilgi teknolojilerinin, internet tabanl uygulamaların ve platformların ögretim, ögretmen eğitimi ve mesleki gelişim de dahil olmak üzere hayatımızın hemen hemen her alanına hızl, yaygın ve güçlü bir şekilde nüfuzuna tanıklık etmekteyiz. Bu önermeden yola çıkarak, mevcut çalışma Türkiye'deki İngilizce öğretmenlerine mesleki gelişim ağları olarak hizmet veren Facebook gruplarının sistematik bir analizini yapmayı hedeflemektedir. Bu çalışmada kullanılan iki aşamalı analiz, gözlemlemeyi bir veri toplama stratejisi olarak ve tematik içerik analizini de analitik bir lens olarak benimsemektedir. İlk seviye olan makro analiz, bu grupların $(n=55)$ üye sayları, grup isimleri, tanımları ve profil fotoğrafları yoluyla kendilerini nasıl konumlandırdıklarını analiz etmektedir. İkinci seviye olan mikro analiz ise ilgili gruplar arasında seçilen iki farklı grupta 2020 yıl Haziran ayında yapılan paylaşımlara (sırasıyla $n=189, n=1063$ ve toplam $n=1252$ ) odaklanarak grup içi etkinliklere ışık tutmaktadır. İki seviyeli analiz bizlere bu grupların faydacı (çoğunlukla bilgi veya öğretim videoları, revizyon testleri gibi dokümanlar isteme/paylaşma) ve sosyal merkezli (aynı mesleki temele, gündelik gerçekliğe sahip meslektaşlar arasında yapılan sosyal paylaşımlar) olarak tanımlanabileceğini göstermektedir. Bu nedenle, bu grupların, (aynı uzmanlık alanından gelen) öğretmenleri bir araya getiren profesyonel odakl sosyalleșme alanlar ve aynı zamanda mesleki, lojistik ve idari konularda etkileşime girdikleri, tartışma ve paylaşımlar yaptıkları dijital zümre odaları gibi hizmet ettiği sonucuna varilabilir.

Anahtar Kelimeler: Mesleki Gelişim, Sosyal Media, İngilizce Öğretmenleri, Facebook

${ }^{3}$ Orta Doğu Teknik Üniversitesi Eğitim ve Beșeri Bilimler İngilizce Öğretmenliği Programı, selvi@metu.edu.tr, ORCID: 0000-0002-1122-9770 


\section{Introduction}

What is the first thing that you do when you open our eyes in the morning and the last thing you do before going to sleep at night? Chances are, your answer to this question is "checking my social media account on my mobile device," like millions of other people (Keating, 2017). Recent years have witnessed a rapid and widespread proliferation of information technologies and internet-based applications and platforms, commonly referred to as social media, which powerfully infused into almost every aspect of our lives (Selwyn \& Stirling, 2016). These tools are now an indispensable part of modern everyday life (Miller et al., 2016) and became "the primary platform for many people's engagement with the internet" (Selwyn \& Stirling, 2016, p. 2). More interestingly, these tools transform our ingrained notions of about language, education, interpersonal communication, collaboration, and connection, eliminate the traditional barriers in communication such as time and space, and afford us with both tools and medium to generate, access, share, and exchange content (textual, visual, audiovisual or multimodal), and interacts with others (tag, comment, post, like, react).

Today, "from psychiatrists to education scholars, from biologists to mathematicians, it seems that the potential (and drawbacks) of social media are debated across disciplinary lines" (Veletsianos, 2016, p. 5). The omnipresence of these environments and their increasing utilization for pedagogical affordances (and constraints) (see Manca \& Raineri, 2013 for a summary of these affordances) spurred great interest among scholars in a range of subfields in ELT, including second/foreign language pedagogy and assessment, second language acquisition (SLA), discourse analysis, computer-mediated communication (CMC), sociolinguistics, and language teacher education (see Reinhardt, 2019 for an overview of the utilization of social media in second and foreign language teaching and learning).

The use of social media platforms in education is not limited to supporting pedagogical practices. These environments also serve to be fertile grounds for pre- and in-service teacher education and professional development-facilitating enhanced interactions, developing (professional) identity, promoting a sense of community, spearheading collaboration, inducing discussions, serving as contexts for in-depth reflections, creating opportunities for feedback, serving as contexts of support in the processes of field experience, mentoring and continuing professional development (Aydın, 2012; Carpenter \& Krutka, 2015; Iredale et al., 2020). These affordances are particularly important for those teachers who are interested in their professional development yet constantly grapple with the challenges of geographical remoteness and dispersion and limited instructional/professional resources (Patahuddin \& Logan, 2019).

The current study is a response to the recent calls by Rodríguez-Hoyos, Haya and Fernández-Diáz (2015) and Manca and Raineri (2017) who underscored the importance of broadening the lines of research on social networking sites and including un(der)explored dimensions, such as informal professional development of language teachers. Taking this perspective into account, the overarching aim of this study is to systematically analyze Facebook groups for ELT professionals.

\section{Social Media: What is it and What Does it Offer to Teachers?}

As a result of the proliferation and rapid yet dynamic evolution of social media platforms, our understanding of what constitutes a social networking site and what it offers for its users has also shifted remarkably. Within the scope of this paper, the more recent and revisited definition by Ellison and Boyd (2013, p. 211) has been adopted: 


\begin{abstract}
A social network site is a networked communication platform in which participants 1) have uniquely identifiable profiles that consist of user-supplied content, content provided by other users, and/or system-level data; 2) can publicly articulate connections that can be viewed and traversed by others; and 3) can consume, produce, and/or interact with streams of usergenerated content provided by their connections on the site.
\end{abstract}

These platforms offer a wide range of features and possibilities to its users-social networking sites (e.g., Facebook, Twitter), media sharing networks (e.g., Instagram, YouTube, TikTok), discussion forums (e.g., Reddit, Quora, Digg), consumer review platforms (e.g., Yelp, TripAdvisor), bookmarking and content curation (e.g., Pinterest, Flipboard), blogging and self-publishing (e.g., WordPress, Tumblr, Medium), among others (Foreman, 2017). Thus, as of January 2020, nearly 4 billion people stay connected using at least one of these platforms (Kemp, 2020).

Even though these environments have originally been created for socialization purposes, their value, significance, and prospects have gradually been recognized by educators. Inherent characteristics of social media platforms such as "networking," "communication platform," "content," "connections," and "consumption, production, and interaction with content/users," in Ellison and Boyd's (2013) terms, have all contributed to their repurposing as new and unorthodox alternatives of mainstream professional development (Bissessar, 2014). For all these reasons combined, educators are now utilizing social networking sites more than ever. More recently, the ongoing COVID-19 pandemic around the world brings about a set of unprecedented challenges for millions of learners, educators, and teacher educators. In this picture, online platforms and activities (including those that occur in social media) serve as transformative and adaptive responses ensuring the sustainability of continued professional development by connecting educators from separate locations with each other and offering an (in)formal and alternative professional development environment in a flexible way.

\title{
Facebook as an Informal Professional Development Space
}

Founded in 2004, with a corporate mission to "give people the power to build community and bring the world closer together," Facebook operates under the principles of giving people a voice, serving everyone, building connecting and community, promoting economic opportunity and keeping people safe and protecting privacy (Facebook, n.d.). ith more than 2 billion monthly active users, Facebook stands out as a prime social networking choice for people around the world, and Turkey is not an exception. As of January 2020, there are 62.07 million internet users in Turkey, accounting for nearly 65\% of the entire population (Kemp, 2020). 54 millions of internet users (about 87\%) in the country use social media platforms, which accounts for an additional 4.2\% (or 2.2. million) change as compared to January 2019. Even though Facebook is now the fourth most used social media platform among the internet users aged 16 to 64 in Turkey (after YouTube, Instagram, and WhatsApp, respectively) (Kemp, 2020), its versatile nature and a range of applications allow its users to stay connected.

Since its inception, Facebook increasingly began to function as a transformative context for teaching and learning (and eventually pre-/in-service teacher education), and a fertile research ground for scholars interested in scrutinizing individuals, artifacts, connections, interactions, and processes therein. On the one hand, it offers opportunities for engagement in lifelong professional development (Staudt, St. Clair, \& Martinez, 2013) and co-constructing shared repertoires (Lantz-Andersson, Lundin \& Selwyn (2018) in a range of topics (Bissessar, 2014). On the other hand, it brings about challenges such as negotiating social pressures, privacy, and the separation of professional and professional life and identities therein (Fox \& Bird, 2017). For some researchers, social networking sites (including Facebook) mean a process by which educators project their professional identity and build, maintain and stay connected with their professional network-known as 
"educational networking” (Peña-Ayala, 2020). For others, it means a context within which educators generate, access, share, and exchange content (textual, visual, audiovisual or multimodal) and interact (tag, comment, post, like, react) with fellow educators in different places either synchronously or asynchronously-known as "virtual professional learning community" (Bedford, 2019) or "networked professional learning community" (Prenger, Poortman \& Handelzalts, 2019). Considering that age demographics on Facebook indicate that the users between 25 and 54 years of age constitute the biggest group both globally (60\%, Statista, 2021a) and locally $(65.5 \%$, Statista, 2021b), this platform stands out as a viable context of interaction, connectivity and professional development for professionals, including teachers.

These virtual communities of practice (vCoPs) for ELT professionals on Facebook, or Communities of Practice in Facebook or CoPiF (İ. Yıldırım, 2019), is the primary focus of the current inquiry and in line with the Networks of Practice framework (Ranieri, Manca \& Fini, 2012) - an extension of Lave \& Wenger's (1991) Communities of Practice ( $\mathrm{CoP})$ that views professional development as socially situated processes embedded within an activity, context and culture in loosely regulated and coordinated networks. Thus, these groups are characterized by three fundamental elements: (1) joint enterprise (collective understanding of the phenomenon that brings together members, i.e., professional development in ELT), (2) mutuality (mutual engagement towards a particular issue, i.e., members invested in, interacting with and learning from each other), (3) shared repertoires (shared forms, ways, and processes of addressing professional matters, i.e., shared professional literature, background, contextual dynamics, and profession-specific vocabulary, among others) (Wenger, 2000). Manca and Rainieri (2013) adopt a more global perspective and categorize Facebook groups for teachers could under two categories-generic and thematic groups. While the former refers to those groups in which teachers share their personal experiences related to various aspects of education, the latter refers to those groups with a particular focus, such as an instructional material exchange.

Parallel to the proliferation of research studies focusing on social media in the last decade, scholars in Turkey developed a growing interest in scrutinizing the role and importance of Facebook for teacher education and professional development in the local context. Current themes include Facebook as an instructional environment and communication channel with language users (Börekçi \& Aydın, 2019; Delen, 2017; Ekoç, 2014; Özdemir, 2017), its effectiveness in pre-service teacher education courses (Demiraslan Çevik, Çelik \& Haşlaman, 2014; Küçük \& Şahin, 2013; Öztürk, 2015), and pre- and in-service teachers' beliefs, usage habits, activities and development (Atmaca, 2014; Balçıkanlı, 2015; Biçen, Özdamlı \& Uzunboylu, 2014; Cinkara \& Yalçın Arslan, 2017; Sumuer, Esfer \& Yıldırım, S., 2014). Nevertheless, even a quick overview of the studies conducted in the local context presents an incomplete and fragmented picture of the role, value, and impact of Facebook groups for professional development, especially in the field of ELT teacher education (with the exception of Deniz (2016) and Yıldırım, 2019)). The contextual (i.e., positioning of Facebook groups through macro-level analysis and activities and interactions therein through micro-level analysis) and professional foci (i.e., Facebook groups specifically for ELT professionals) adopted in the current study distinguish the present inquiry from other studies in the literature. Therefore, the current study aims to fill this gap in the literature by providing a systematic analysis of Facebook groups serving as networks of professional development for ELT professionals in Turkey. More specifically, it aims to investigate the following research questions-(1) How do Facebook groups established for ELT professionals in Turkey position themselves? (2) What types of activities and interactions occur in focal Facebook groups established for ELT professionals in Turkey? 


\section{Method}

\section{Data sources, collection, and analysis}

The current inquiry was built upon a systematic collection of non-elicited data for archival purposes through non-participatory activity (known as "lurking") for the purposes of descriptive interpretations of these observations (Nonnecke \& Preece, 2000). This unobtrusive or passive immersive mode enables researchers to be "invisible onlookers" in a context-dependent fashion (Lenihan, 2011, p. 55) systematically observing, familiarizing themselves, and analyzing the culture in these digital spaces. Despite some criticism for not being truly ethnographic, this method has recently been adopted by scholars conducting investigations focusing on online communities for teachers (e.g., Bernard, Weiss \& Abeles, 2018; Tønnessen, 2019). Considering the fact there is no significant difference between lurking and being a part of the community for most participants, these criticisms driven by traditional formulations of ethnography have been ignored within the scope of this project.

The research process began by preliminary and raw searches using the platform's built-in search engine and various keywords (e.g., "İngilizce öğretmenleri," "ELT Turkey," "İngilizce Türkiye”) that would yield to the groups with potentially rich data to answer the research question under investigation (see Figure 1 below summarizing the process). The initial search resulted in a total of 164 groups.
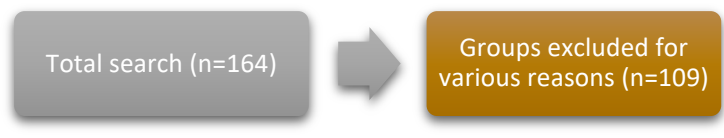

Figure 1. Group Selection Process - A Global Overview

The list has been sorted, cleaned and analyzed using the following inclusion criteria: (1) Relevance: The groups for individual members, events, institutions or those related to ELT but not teachers and professional development have been eliminated from the study, (2) Language of communication: No language criterion was adopted, meaning that groups using either Turkish or English were included in the data analysis process. In the end, a total of 55 groups have been identified for the first phase of the study, which aims to portray a big picture snapshot of Facebook groups established for ELT professionals in Turkey.

Table 1

Coding Sample for Macro Analysis

\begin{tabular}{llllll}
\hline Title & Size & Founded in & Type & URL & Group Cover Photo \\
\hline ELT Group & $50,000+$ & $2010-2014$ & Private & $\begin{array}{l}\text { [here comes } \\
\text { the URL }]\end{array}$ & Saved \\
\hline
\end{tabular}

The focal groups for the second phase of the study (summarized in Table 2) which involves individual case analysis were chosen on the basis of the following criteria: Focus (the groups must be for ELT professionals), size (the groups must have the largest audience), daily/monthly activities (the groups must be the most active platforms on Facebook to promote professional development for ELT professionals) and the presence of artifacts (the groups should have textual, audiovisual and multimodal artifacts available for its members). 
Table 2

Focal Facebook Groups (Ordered by Size)

\begin{tabular}{lllll}
\hline Group & $\begin{array}{l}\text { Group } \\
\text { Size }\end{array}$ & $\begin{array}{l}\text { New } \\
\text { Posts } \\
\text { Today }^{*}\end{array}$ & $\begin{array}{l}\text { Posts in } \\
\text { last 30 } \\
\text { days }^{*}\end{array}$ & Type \\
\hline ELT Group 1 & $50,000+$ & 3 & 175 & Private \\
ELT Group 2 & $40,000+$ & 33 & 1,080 & Private \\
\hline${ }^{*}$ All information about these groups is as of July 5, 2020. & & &
\end{tabular}

The data reported in this study were drawn from two major sources: (1) the profile data of Facebook groups (e.g., title, group size, type, description, group cover photo, new posts today, posts in last 30 days, and URL) established for the professional development of ELT professionals in Turkey, (2) posts from the focal groups. Any data in Turkish were translated into English by the researcher. In this project, data have been collected, stored, and coded in an Excel sheet. The asynchronous nature of these groups enabled the researcher not just to collect data after it has been shared in these groups but also to verify data by making constant comparisons between the original source and the coding sheet. The data collection period lasted from June 1, 2020 to June 30,2020 and resulted in a total of 1,252 posts in these groups. New data were collected and coded using the coding sheet (see Table 3 below) on a weekly basis. In order to prevent any miscoding, the coding sheet has been cross-checked at the end of the data collection process.

Table 3

Coding Sample for Micro Analysis

\begin{tabular}{|c|c|c|c|c|c|c|c|}
\hline Group & Post & & Content & Date & Likes & Comments & Code \\
\hline ELT Group 1 & $\begin{array}{l}\text { [Here comes the } \\
\text { translation of the post] }\end{array}$ & English & $\begin{array}{c}\text { Text }+ \\
\text { Hyperlink }\end{array}$ & $\begin{array}{c}\text { June } \\
1\end{array}$ & 3 & 0 & Research \\
\hline
\end{tabular}

Data collected from Facebook groups established for ELT professionals in Turkey were analyzed through an iterative two-phased thematic content analysis (Krippendorf, 2018). This has been deemed appropriate as a methodological tool to handle a large quantity of data in the project, which eventually keeps the overarching focus of the project on the connections and activities in these spaces rather than on individuals per se. Aligned with the socially situated nature of connections, nodes of knowledge and activity in these spaces, thematic content analysis was useful in identifying patterns in the data in both macro- and micro-level analyses of the project (Braun \& Clarke, 2006). Macro level analysis involved a bird-eye view to the data and focused on (1) providing descriptive data (i.e., size), and (2) identifying patterns in choices made by these groups in describing their stance (i.e., titles, descriptions and group cover photos). Micro-level analysis, on the other hand, took a closer look at these groups and their activity patterns (i.e., posts). The first phase of micro-level analysis involved the development of an initial thematic web of connections using a smaller sample $(n=100)$ of posts, using the Braun and Clarke's (2006) widely adopted thematic analysis steps. The second phase involved a larger sample $(n=1,252)$ validating the thematic categories developed in the first phase of the study. 


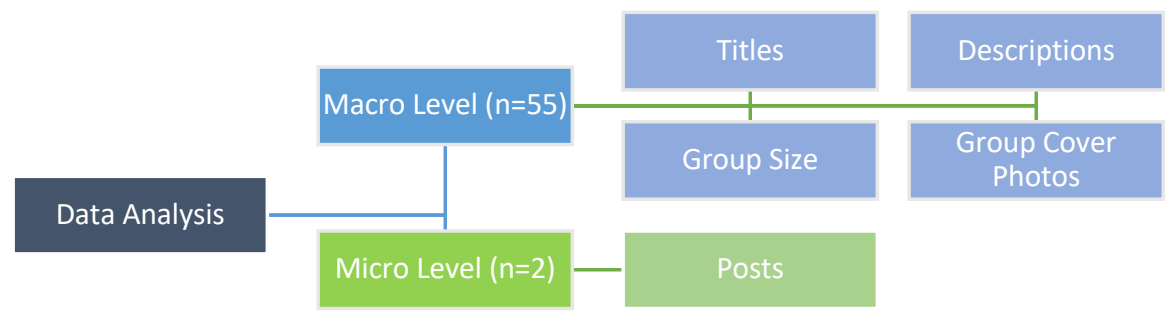

Figure 2. Data Sources and Levels of Analysis - An Overview

\section{Ethical Considerations}

Just like any research study, ethical considerations were taken into account (in)forming methodological decisions made throughout the research process. The recent interest in Facebook (or any online communities, for that matter) as a fertile ground for scholarly inquiry brings about a set of ethical dilemmas and responsibilities for researchers, which may be resolved only by critical decisions that adhere to the ethical guidelines established by professional/scholarly communities and/or organizations. Following the American Educational Research Association's (AERA) Ethical Guidelines (2011), we define the data available in these Facebook groups as "semi-public" since they are available to anyone who go through an easy membership process. Despite the fact that present study neither adopts a discourse analysis focus nor focuses on individual members in these groups, and the research process (and dissemination of research findings) does not pose any risks or conflicts of interest to the online communities under scrutiny (Coughlan \& Perryman, 2015), any identifiable information in the study have been anonymized to protect these structures and the users participating therein. Considering that the data collected in the study are collected by observation of individuals in semi-public spaces and treated textually in an anonymized fashion (Willis, 2017), it is not classified as human subject research. Since the primary focus of this study is to observe and document patterns of activity, any identifiable personal information was either removed from the study or anonymized for further use. Furthermore, considering that a great bulk of these posts are in Turkish, their translation into English further facilitated the anonymity of these posts and their authors. Due to the nature of the study, informed consent or ethics committee approval was not required.

\section{Results}

\section{Macro-Level Analysis}

The purpose of the macro level analysis was to provide a global overview of these groups (determined by their size) and purpose (determined by their titles, description, and group cover photos). Collectively, these elements set the first impression for new and potential members.

\section{Group characteristics: Size and titles}

In all, 55 individual Facebook groups fulfilled the initial inclusion criteria (shown in Figure 1 earlier). The groups included in the study ranged in size from 358 to 55,136 members and had a median of 11,521 members (IQR 5,487-20,469). With the exception of one that adopted a Turkish-English title, the groups focused in this study predominantly adopted Turkish-only titles (92.7\% or 51/55), while the rest relied on English in their titles $(5.4 \%$ or $3 / 55)$. The most widely used words in the titles are "English teacher(s)" ( $=40)$, "platform" $(\mathrm{n}=15)$, "paylaşım (sharing)" ( $\mathrm{n}=14)$, and "ELT" $(\mathrm{n}=4)$. None of the groups have an explicit emphasis on "professional development" reflected in their titles. In sum, it could be argued that most of these groups defined 
themselves in pragmatic terms, as sharing platforms for ELT professionals. As summarized in Table 4 below, when analyzed in greater detail based on their titles, the groups may be categorized using and extending Manca and Rainieri (2013)'s typology: (1) generic groups (40\% or 22/55) - groups that do not specify their purpose in their titles (e.g., "English Teachers," "English Language Teachers' Group," “I am an English teacher," etc.), (2) thematic groups (60\% or 33/55) - groups that specify their particular purpose in their titles (e.g., "Platform for Primary School English Teachers," "Material Exchange Group for English Language Teachers," etc.

Table 4

Categorization of Groups by Their Purpose

\begin{tabular}{|c|c|c|c|}
\hline Types & Sub-Categories & Groups & Examples of Group Titles \\
\hline Generic & $\mathrm{n} / \mathrm{a}$ & $\begin{array}{l}40 \% \\
(22 / 55)\end{array}$ & $\begin{array}{l}\text { English Teachers } \\
\text { English Language Teachers' Group }\end{array}$ \\
\hline \multirow{2}{*}{ Thematic } & $\begin{array}{l}\text { Type/Level (middle school, private } \\
\text { school, etc.) }\end{array}$ & $\begin{array}{l}32.7 \% \\
(18 / 55)\end{array}$ & $\begin{array}{l}\text { High School English Teachers } \\
\text { The Platform for Primary School } \\
\text { English Teachers }\end{array}$ \\
\hline & $\begin{array}{l}\text { Professional matters (sharing } \\
\text { materials, solidarity, etc.) }\end{array}$ & $\begin{array}{l}27.2 \% \\
(15 / 55)\end{array}$ & $\begin{array}{l}\text { Material Exchange Group for English } \\
\text { Language Teachers } \\
\text { English Teachers Solidarity Group }\end{array}$ \\
\hline
\end{tabular}

When broken down for individual sub-groups, thematic groups include (2.a.) groups by level (high school, middle school, etc.) or type (private schools) accounting for $32.7 \%$ of the groups in this category (18/55), and (2.b.) groups by a professional matter (sharing materials, recruitment support in public schools, solidarity, etc.) accounting for $27.2 \%$ of the groups in this category $(15 / 55)$.

\section{Group characteristics: Purposes}

Facebook groups feature a section called 'About,' which provides a succinct and introductory description of the group. A great majority of the groups identified and included in the current investigation $(72.7 \%$ or $40 / 55)$ utilized this feature and included some kind of description outlining their overarching description. The rest of the groups $(27.2 \%$ or $15 / 55)$ were discarded from the analysis due to either not having any text at all (12.7\% or 7/55) or including minimal text that yields to no meaningful analysis (e.g., "English teachers," "middle school English teachers," etc.) (14.5\% or 8/55). The linguistic choices in group descriptions are similar to that of in titles. In other words, most of the groups adopted Turkish to convey their descriptions (90\% or 36/40), while others utilized either English (7.5\% or 3/40) or bilingual (Turkish-English) descriptions (2.5\% or 1/40). When analyzed more closely, the groups in the current investigation utilized their About pages for four main reasons. First and foremost, almost all groups defined themselves as spaces or platforms where ELT professionals can exchange materials/documents, news, events, resources, and ideas. This pragmatic nature of these groups are exemplified as follows: "Either a worksheet you produce, a creative project by your students, a book you love, a funny or interesting event that happened to you in your classes, an educational method you favor... i.e., anything that springs to your mind." Second, a common pattern observed almost in the descriptions of every single group was that they made an explicit emphasis on the notion of community. Thus, expressions such as "not a group but a family," "a common meeting point," "a common denominator" are testaments to the collective nature of these groups. Exclusionary (e.g., "Parents and teachers specializing in other subjects are not accepted into the group") and inclusionary statements (e.g., "Sometimes memes, sometimes jokes, but mostly posts related to our field") define the parameters of the notion of 'community.' While the former brings 
ELT professionals under one roof, the latter keeps them there by entertaining them. Third, many groups used their About page to define their ground rules for inclusion (e.g., "If you fail to share a proof of your role as a teacher with one of our administrators, your membership will not be approved"), interaction (e.g., "It is a crime to insult Mr. President, Mr. Prime Minister and other statesmen in the group's posts, and the person making such remarks will be responsible for these insults," "Posts and comments involving hate crimes, targeting a particular ethnic or religious identity, prioritizing ideological stance or racial identity, provoking individuals/groups or leading to revenge, hatred, animosity are forbidden"), participation (e.g., "When posting, let's be cognizant of and pay utmost respect to copyrights"), and agreement (e.g., "Anyone who joins the group is deemed to have accepted these rules"). These rules also include the consequences of not following group rules (e.g., warning for three times, deletion of the post, temporary/permanent expulsion from the group, or a legal lawsuit). Finally, groups also utilized their group description to provide the links for their website, social media presence in other platforms (e.g., YouTube, Instagram, Pinterest), and other related Facebook groups.

\section{Group characteristics: Group profile photos}

Similar to group titles, group cover photos reflect the deliberate choices of the group administrators and, at the same time, convey important meanings about the group. In other words, they give us ideas on the primary and/or secondary aspects to be foregrounded by these groups. A small portion of the groups in the study ( $9 \%$ or 5/55) did not have a customized group cover photo and, therefore, utilized the generic and default image provided by Facebook to portray their identity. The rest of the groups (91\% or 50/55) use some kind of image, including visual and textual elements (see Table 5 below). When analyzed more closely, most of these groups view these images to convey a motto about their group/community (e.g., "Where we teach, learn and share"), communicate their title (e.g., "ELT Turkey") and external connections (e.g., affiliated website links) and situate themselves within the local context (e.g., Turkish flag, a portrait of Mustafa Kemal Atatürk, a map of Turkey, etc.). In addition to these meaningful choices, many groups use images that are not connected to ELT teachers, education or teaching, in general (e.g., watermelon in a flowing river, a cute kitten, among others). Three possible scenarios may explain these choices: First, they may be careless visual choices by the group administrators. Second, since group cover photos appear as new posts in groups, these unrelated images may spearhead discussions often beyond the realm of professional scope of these groups and thereby offer a much wider sense of community. Finally, they may just be choices with intentions to generate positive feelings. 
Table 5

The Themes of Group Profile Photos in the Study

\begin{tabular}{|c|c|c|c|}
\hline Themes & (T)ext/(I)mage & $\mathbf{n}$ & Examples \\
\hline & & & High-quality ELT materials \\
\hline \multirow[t]{3}{*}{ Motto } & $\mathrm{T}$ & 22 & Together and towards a better future \\
\hline & & & Where we teach, learn and share \\
\hline & & & The Platform for English Language Teachers in Turkey \\
\hline \multirow[t]{3}{*}{ Group Title } & $\mathrm{T}$ & 18 & ELT Turkey \\
\hline & & & English Language Teachers Consulting \\
\hline & & & Watermelon in a flowing river \\
\hline \multirow[t]{2}{*}{ Unrelated images } & I & 14 & A cute kitten \\
\hline & & & Five stars \\
\hline \multirow{3}{*}{ Affiliated website link } & $\mathrm{T}$ & 10 & [here comes the URL] \\
\hline & 1 & 10 & [here comes the URL] \\
\hline & & & Turkish flag \\
\hline \multirow[t]{2}{*}{ Local identity } & I & 9 & A portrait of Mustafa Kemal Atatürk \\
\hline & & & A map of Turkey \\
\hline \multirow[t]{2}{*}{ Commercial } & I & 7 & ELT textbooks by various commercial publishers \\
\hline & & & Children holding a banner \\
\hline \multirow[t]{3}{*}{ Children } & I & 7 & Children jumping and smiling \\
\hline & & & Children working on computers \\
\hline & & & A notepad and a pen \\
\hline \multirow[t]{2}{*}{ Professional life } & I & 5 & Teacher silhouettes in front of a blackboard \\
\hline & & & Mobile devices, certificate, globe, and a graduation cap \\
\hline \multirow{2}{*}{ Sense of community } & I & 3 & A group of people on a table which has the word \\
\hline & 1 & 3 & "English" underlined in yellow \\
\hline \multirow{2}{*}{ Words } & $\mathrm{T}$ & 4 & Teachers \\
\hline & & 4 & Welcome \\
\hline
\end{tabular}

\section{Micro-level Analysis}

The purpose of the macro level analysis was to provide a refined analysis of the activities in these groups. Facebook enables its users to engage in activities through various options: (1) posting something (a text, an image, a video, a hyperlink, a document or a combination of these), (2) liking a post, (3) commenting on a post, and (4) sharing a post. Therefore, the data for micro analysis (i.e., posts) came from two focal Facebook groups established for ELT professionals in Turkey.

\section{Group posts: A global view}

After removing duplicates, unavailable content, and broken links, the posts shared in the focal Facebook groups ( $n=189$ and $n=1,063$, respectively, and a total of $n=1,252)$ were coded for further analysis. With the exception of a few, all the posts and comments were in Turkish. The communication pattern and flow observed in these groups could be defined as unidirectional (92 posts $(0.73 \%)$ received neither likes nor comments, 394 posts (31.4\%) received no comments, 529 posts (42.2\%) received ten or fewer comments).

If we define user activity on Facebook in terms of "likes" and "comments," then a quick focus on these may reveal patterns about users. The posts that received top likes were (1) the group administrator announcing that he and his family were exposed to a person in his apartment building who tested positive for COVID-19 and therefore was quarantined (1,400+ likes), (2) a teacher's comment on students' absenteeism during the online teaching period (1,400+ likes), (3) the group administrator's prediction about the online modality for 
professional development (1,300+ likes), (4) the group administrator announcing the end of imposed quarantine period (1,200+ likes), and (5) nostalgia for obsolete coursebooks (1,100+ likes). On the other hand, the top posts that received the most comments were (1) the group administrator announcing that he and his family were exposed to a person in his apartment building who tested positive for COVID-19 and therefore was imposed a quarantine (969 comments), (2) the administrator asking for the age of first job placement (531 comments), (3) a teacher developing bilingual books (504 comments), (4) nostalgia for obsolete coursebooks (333 comments), and (5) people's misconceptions about group members future careers (262 comments). Collectively, these figures revealed the mixed nature and purpose of these groups. In other words, even though professional characteristics (i.e., being an ELT professional) serve as the ultimate motivation (and indexed in the titles and descriptions of these groups, as well as content and discoursal choices in the communication therein) that bring these users together in these online contexts, these spaces afford social interaction for individuals with a range of personal and professional identities. In that regard, these groups operate as "sociotechnical interaction networks" (Kling, McKim \& King, 2003) in which boundaries, relations, (personal/professional) identities and learning are becoming increasingly blurred.

The posts shared in the focal Facebook groups also exhibited a variety and combination in terms of their structure (see Figure 3 below). The users in these groups utilize every single combination of features available to them.

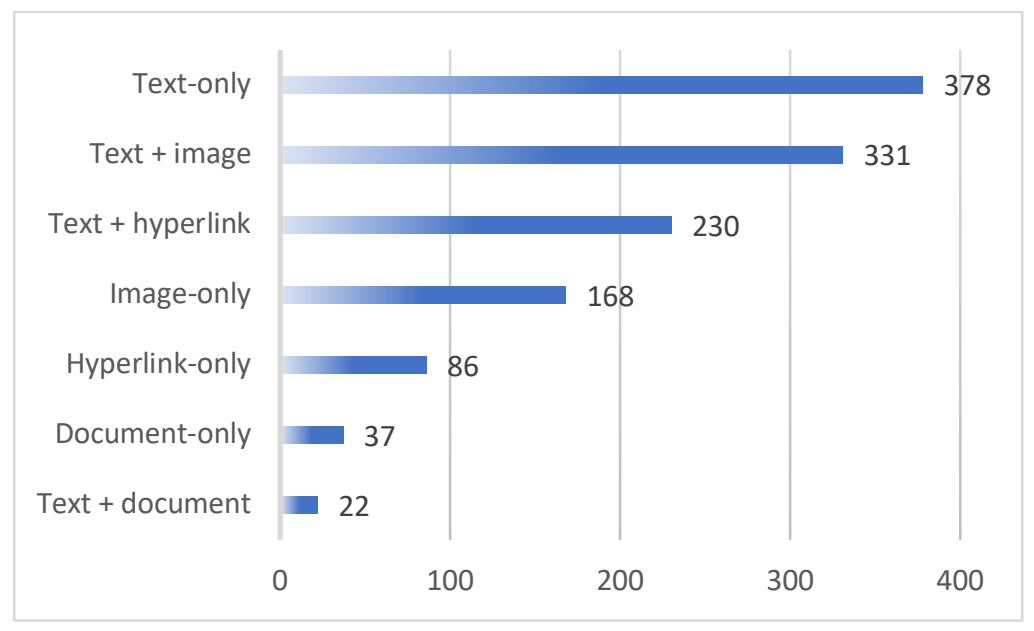

Figure 3. Types of Posts Shared in the Focal Facebook Groups

Two important points of considerations should be added to the discussion-First, even when the most liked $(1,400+$ likes) and most commented post (969 comments) were put under the microscope, they account only for $2.8 \%$ and $1.9 \%$, respectively, of the members in the group within which these posts appeared. This means that a great majority of members in these groups are not observable participants in the groups' activities, known as lurkers. Second, it is not possible to simply define the silent majority in these groups as nonparticipants or free-riders since the "impact" data (e.g., number of downloads, members' utilization of the information and artifacts shared in these groups, etc.) were neither available and within the scope of the current project.

\section{Group posts: Themes and subthemes}

Thematic analysis conducted on posts shared in the focal Facebook groups resulted in a total of 10 themes and subthemes (see Table 6 below). Each of these themes could be perceived as various dimensions or distinct functions of these groups and need greater scrutiny. 
Table 6

The Themes of Posts Shared in the Focal Facebook Groups

\begin{tabular}{|c|c|c|c|}
\hline Themes & Subthemes & $\mathbf{N}$ & $\%$ \\
\hline Social & $\begin{array}{l}\text { Audiovisuals/videos for entertainment, community building, } \\
\text { posts on social/political matters, nostalgia }\end{array}$ & 420 & $33.5 \%$ \\
\hline Administrative & $\begin{array}{l}\text { Issues, questions, tutorials on the processes, platforms, and } \\
\text { documents used by public school teachers, rules and } \\
\text { regulations }\end{array}$ & 232 & $18.5 \%$ \\
\hline Assessment-oriented & $\begin{array}{l}\text { Revision tests, online quizzes, updates/announcements on } \\
\text { standardized tests, seeking external help on a test question }\end{array}$ & 130 & $10.3 \%$ \\
\hline Instructional & $\begin{array}{l}\text { Teaching tip, student work, instructional videos, } \\
\text { supplementary activities and materials, advice and help on } \\
\text { instructional matters, obsolete instructional materials }\end{array}$ & 114 & $9.1 \%$ \\
\hline Professional development & $\begin{array}{l}\text { Webinars, sharing personal views on professional matters, blog } \\
\text { posts }\end{array}$ & 111 & $8.8 \%$ \\
\hline Miscellaneous & $\begin{array}{l}\text { COVID-19-related updates/queries, updates from the admins, } \\
\text { updates from schools }\end{array}$ & 94 & $7.5 \%$ \\
\hline Career-related & Job announcements, relocation advice, working conditions & 54 & $4.3 \%$ \\
\hline Personal & Various non-professional and personal matters & 49 & $3.9 \%$ \\
\hline Language-related & $\begin{array}{l}\text { Language related questions, intercultural aspects of } \\
\text { communication, translation }\end{array}$ & 27 & $2.1 \%$ \\
\hline Research-oriented & Invitation for participation, requests for books/articles & 21 & $1.6 \%$ \\
\hline TOTAL & & 1,252 & $100 \%$ \\
\hline
\end{tabular}

The great majority of the posts shared in the time period $(n=420$ or $33.5 \%)$ are social in their nature. They cover a range of subthemes including images, videos or hyperlinks shared for entertainment (e.g., baby panda eating fresh bamboo for lunch or an election campaign poster for the municipality of Mars featuring Elon Musk with a mustache), community building (e.g., sharing a song or an image of sunset, Father's Day celebration messages), posts on social/political matters (e.g., posts on Black Live Matters protests in the US, condemning the killing of a civilian boy killed by terrorists in Turkey), and nostalgia (e.g., old cassette players and Walkman). Even though no data were collected from group participants about their purposes for joining these groups, one of the administrators actually posed this to the audience in his group (receiving 67 likes, 117 comments). A great majority of the respondents (although representing $0.2 \%$ of the member body) highlighted the social and shared community aspect of this group using such keywords as "sincere," "fun," "being on the same wavelength," "being a big family," "getting information/instructional materials." Responding to one of the members, the group administrator underscored that their priority was primarily to create a community and secondarily exchanging other artifacts (e.g., instructional materials, documents, etc.).As a manifestation of this social bond, most of the group participants in these groups (as well as in other social spaces such as forums or other social networking sites such as Twitter) refer to each other as zümrem/zümrecan (my fellow colleague) - an inclusive lexical choice indexing and fostering membership in a community of practice and sociotechnical proximity.

Posts categorized as administrative ( $\mathrm{n}=232$ or $18.5 \%$ ) covered a range of subthemes including issues, questions, tutorials on the processes, platforms, and documents used by public school teachers (e.g., the platform used by public school teachers for online teaching during the COVID-19 period, professional development seminar reports, group meeting minutes document), rules and regulations (e.g., rules governing maternity leave, an update on recent changes concerning the points accrued for various professional activities). Administrative posts, when combined with those under Social, account for more than half of the posts in the data set $(\mathrm{n}=652$ or $52 \%)$. 
Posts centred on assessment ( $\mathrm{n}=130$ or $10.3 \%$ ) include a number of different subthemes such as revision tests (e.g., sample prep test for standardized exams), online quizzes (e.g., asking for unit tests or quizzes), updates/announcements on standardized tests (e.g., health advisory the partial curfew implemented in Turkey on the days of high school and university entrance exams), seeking external help on a test question (e.g., a teacher debating on the two options in a multiple-choice exam question). Since two major exams concerning ELT professionals happened in June, namely High School Entrance System (LGS) on June 20, and Higher Education Institutions Examination (YKS) on June 27, it could be assumed that the data set included a higher number and percentage of posts related to assessment as compared to other times of the year.

Posts focusing on instructional matters ( $\mathrm{n}=114$ or 9.1\%) encompassed a number of subthemes including teaching tip (e.g., asking/giving tips on private tutoring), student work (e.g., a video showcasing a student performing an in-class task), instructional videos (e.g., YouTube links on various language points or (sub)skills), supplementary activities and materials (e.g., documents), advice and help on instructional matters (e.g., asking for materials/activities for a particular age and level), and nostalgia for obsolete instructional materials (e.g., a post about Hotline).

Posts related to professional development ( $\mathrm{n}=111$ or $8.8 \%$ ) included announcements for webinars (e.g., a webinar on learner and teacher autonomy organized by Erciyes University ELT Society), sharing a personal view on a professional matter (e.g., members sharing and discussing on the public view that teachers work less and have long vacation periods; advice for novice teachers) and blog posts on various professional development topics (e.g., a blog post to how to help students learn English). Different from other themes, posts centered on professional development offer more opportunities for information exchange and participation.

Posts that are not covered by any of the themes in the study were coded as miscellaneous ( $\mathrm{n}=94$ or $7.5 \%$ ). These posts included COVID-19-related updates/queries (e.g., the group administrator announcing that he and his family was exposed to a person in his apartment building who tested positive for COVID-19 and therefore was quarantined), updates from the admins (e.g., periodic welcomes of new members), updates from schools (e.g., teachers posting pictures of their school buildings). Normally, any miscellaneous category is expected to be rather small in scope and relative size. However, the unprecedented broader conditions imposed on the teachers in these groups by the ongoing pandemic and its ever-evolving implications drastically increased the number of posts in this category.

Career-related posts ( $\mathrm{n}=54$ or $4.3 \%$ ) included subthemes such as job announcements (e.g., vacancies, mostly in private language schools), relocation advice (e.g., teachers asking for tips and suggestions on towns and cities that they soon will move), working conditions (e.g., calculations related to annual raises in 2020). Posts related to personal matters ( $\mathrm{n}=49$ or $3.9 \%$ ) included various non-professional and personal matters (e.g., advice on schools for kids, seeking suggestions on a new mobile phone or laptop, or books for sale by individual group members). As its name suggests, the penultimate theme, language-related posts ( $\mathrm{n}=27$ or $2.1 \%$ ), included subthemes such as language-related questions (e.g., looking for homophone examples in Turkish), intercultural aspects of communication (e.g., saying 'no' in various languages), translations (e.g., requests for translations or verifications on translated texts). The final theme, research-oriented posts $(\mathrm{n}=21$ or $1.6 \%)$, included subthemes such as invitation for participation (e.g., looking for study participants for a study on satisfaction in and improvement of private schools), and requests for books or articles (e.g., looking for a book entitled Literature in the language classroom: A resource book of ideas). 


\section{Discussion and Conclusion}

In essence, the current study aimed to portray the breadth and width of online communities of practice for ELT professionals in Turkey. To achieve this overarching goal, a two-level analysis through lurking as a data collection strategy and thematic content analysis as an analytical lens was deemed necessary to develop more robust results-First, the macro analysis (developing a corpus of these groups and analyzing their titles, description and group cover photos) described the overall scope of these communities. These groups position themselves as spaces exclusively for ELT professionals, pragmatic in nature, emphasizing the notion of the community through titles, group description, group profile photo. Second, the micro analysis (analyzing the activities occurring in two of the most influential groups in June 2020) shed light on the actual activities occurring in these groups. The nature of these groups could be defined as utilitarian (predominantly requesting information and/or providing supplementary docs, instructional videos, revision tests) and sociallyoriented (social exchanges with like-minded colleagues), since these purposes account for every two out of three posts shared in these groups. Collectively, the findings indicate that these groups serve primarily as professionally focused spaces of socialization, like a digital teachers' lounge where teachers (coming from the same area of specialty) interact with each other, socialize but also discuss work, give or ask for help on a range of professional, administrative, logistical and administrative matters.

The findings in this study suggested that the Facebook groups for ELT professionals support the notion of VCoPs, corroborating earlier research in the literature (e.g., Peeters \& Pretorius, 2020; Yıldırım, 2019). Even though the "community" is originally built upon professional "practices" (i.e., being an ELT professional), the content, scope and nature of interaction includes professional (e.g., professional development, career-related, etc.) as well as social (e.g., personal) motives. This "sociotechnical" (Kling, McKim \& King, 2013) understanding of Facebook as a platform for "educational networking" (Peña-Ayala, 2020) suggests that the demarcation between the two (i.e., professional and social) becomes blurrier than ever. It could also be argued that Facebook environment (e.g., tools such as posts, comments, likes, reacts, tags, etc.) and transferrable user experiences therein make positive contributions to the formation of a VCoP.Social media comes with its own unique affordances and constraints. On the one hand, "it sometimes feels as if the social media landscape changes too quickly to fully grasp and leaves scholars permanently lagging behind" (Hogan \& Quan-Haase, 2010 , p. 309). On the other, the exponential growth and importance of these platforms for both pre- and inservice teachers (as well as their future learners, classrooms, and schools) will likely continue. Even though our conceptions of online communities for professional development are still at their infancy (Macià \& García, 2016), the online communities organized in social networking platforms have the potential to transform the teaching discipline in general. To achieve this, we perhaps need to remember Rheingold (2012) who reminds us that "the future of digital culture-yours, mine, and ours-depends on how well we learn to use the media that have infiltrated, amplified, distracted, enriched, and complicated our lives" (p. 1).

Building the results of the current inquiry, the future directions in this area may focus on several points. First, the impact of those groups for ELT professionals for the personal and professional well-being of its members certainly needs more and more thorough investigation. Second, since a great majority of the group participants were not visible or active in group interactions, the notion of participation in these online communities certainly deserves more attention. Finally, thinking about and devising novel ways about learning, teaching, and teacher education/pr in the midst of the ongoing COVID-19 pandemic should be a high priority on the agenda for institutions and educational systems. Thus, it necessitates us to be nimble, resourceful, resilient, and responsive in the online world for the greater good of educators, individuals they work with, institutions they work for, and the societies therein. 


\section{References}

AERA (2011). Code of Ethics. http://www.aera.net/Portals/38/docs/About_AERA/CodeOfEthics\%281\%29.pdf

Atmaca, Ç. (2014). To Facebook or not to Facebook? International Journal of Arts \& Sciences, 7(6), 183-202. Retrieved from http://www.universitypublications.net/ijas/0706/pdf/P4RS167.pdf

Aydın, S. (2012). A review of research on Facebook as an educational environment. Education Technology Research and Development, 60(6), 1093-1106. https://doi.org/10.1007/s11423-012-9260-7

Balçıkanlı, C. (2015). Facebook in teacher education: Adoption, use and educational use. International Journal of Education and Development using Information and Communication Technology (IJEDICT), 11(3), 82-99. Retrieved from https://files.eric.ed.gov/fulltext/EJ1086653.pdf

Bedford, L. (2019). Using social media as a platform for a virtual professional learning. community. Online Learning, 23(3), 120-136. https://doi.org10.24059/olj.v23i3.1538

Bernard, C. F., Weiss, L., \& Abeles, H. (2018). Space to share: Interactions among music teachers in an online community of practice. Bulletin of the Council for Research in Music Education, (215), 75-94. https://doi.org/10.5406/bulcouresmusedu.215.0075

Biçen, H., Özdamlı F., Uzunboylu, H. (2012). Online and blended learning approach on instructional multimedia development courses in teacher education. Interactive Learning Environments, 22(4), 529548. https://doi.org/10.1080/10494820.2012.682586

Bissessar, C. S. (2014). Facebook as an informal teacher professional development tool. Australian Journal of Teacher Education, 39(2), 121-135. https://doi.org/10.14221/ajte.2014v39n2.9

Börekçi, R. \& Aydın, S. (2019). Foreign language teachers' interactions with their students on Facebook. Computer Assisted Language Learning, 4(3), 217-239. https://doi.org/10.1016/j.system.2013.12.001

Carpenter, J. P. \& Krutka, D. G. (2015). Engagement through microblogging: Educator professional development via Twitter. Professional Development in Education, 41(4), 707-728. https://doi.org/10.1080/19415257.2014.939294

Cinkara, E. \& Yalçın Arslan, F. (2017). Content analysis of a Facebook group as a form of mentoring for EFL teachers. English Language Teaching, 10(3), 40-53. https://doi.org/10.5539/elt.v10n3p40

Demiraslan Çevik, Y., Çelik, S., \& Haşlaman, T. (2014). Teacher training through social networking platforms: A case study on Facebook. Australasian Journal of Educational Technology, 30(6), 714-727. https://doi.org/10.14742/ajet.615

Delen, İ. (2017). Teaching argumentation by using Facebook groups. International Journal of Instruction, 10(1), 151-168. https://doi.org/10.12973/iji.2017.10110a

Deniz, İ. D. (2016). Öğretmen mesleki gelişim aracı olarak bir Facebook grubunun incelenmesi [An examination of a Facebook group as a teacher professional development tool] (Unpublished master's thesis), Gaziantep Üniversitesi, Gaziantep, Turkey.

Ekoç, A. (2014). Facebook groups as a supporting tool for language classrooms. The Turkish Online Journal of Distance Education, 15, 18-26. https://doi.org/10.17718/tojde.13403

Ellison, N. B. \& Boyd, D. (2013). Sociality through social network sites. In W. H Dutton (Ed.), The Oxford handbook of internet studies (pp. 151-172). Oxford: Oxford University Press. https://doi.org/10.1093/oxfordhb/9780199589074.013.0008 
Facebook (n.d.). Company info. Retrieved July 5, 2020, from https://about.fb.com/company-info/

Ford, L., Branch, G., \& Moore, G. (2008). Formation of a virtual professional learning community in a combined local and distance doctoral cohort. AACE Journal, 16(2), 161-185. Retrieved from https://www.learntechlib.org/primary/d/24249

Foreman, C. (2017). 10 types of social media and how each can benefit your business. Retrieved July 5, 2020, from https://blog.hootsuite.com/types-of-social-media/

Fox, A. \& Bird, T. (2017). The challenge to professionals of using social media: Teachers in England negotiating personal-professional identities. Education and Information Technologies, 22(2), 647-675. https://doi.org/10.1007/s10639-015-9442-0

Hogan, B. \& Quan-Haase, A. (2010). Persistence and change in social media. Bulletin of Science, Technology \& Society, 30(5), 309-315. https://doi.org/10.1177/0270467610380012

Iredale, A., Stapleford, K., Tremayne, D., Farrell, L., Holbrey, C., Sheridan-Ross, J. (2020). A review and synthesis of the use of social media in initial teacher education. Technology, Pedagogy and Education, 29(1), 19-34. https://doi.org/10.1080/1475939x.2019.1693422

Keating, L. (2017). Survey finds most people check their smartphones before getting out of bed in the morning. Retrieved July 5, 2020, from https://www.techtimes.com/articles/199967/20170302/survey-findspeople-check-smartphones-before-getting-out-bed.htm

Kemp, S. (2020). Digital 2020: Turkey. Retrieved July 5, 2020, from https://datareportal.com/reports/digital2020-turkey

Kling, R., McKim, G. \& King, A. (2003). A bit more to it: Scholarly communication forums as socio-technical interaction networks. Journal of the American Society for Information Science and Technology, 54(1), 47-67. https://www.learntechlib.org/p/95586/.

Küçük, S., \& Şahin, İ. (2013). From the perspective of Community of Inquiry framework: An examination of Facebook uses by pre-service teachers as a learning environment. The Turkish Online Journal of Educational Technology, 12(2), 142-156. Retrieved from http://www.tojet.net/articles/v12i2/12214.pdf

Lantz-Andersson, A., Lundin, M. \& Selwyn, N. (2018). Twenty years of online teacher communities: A systematic review of formally-organized and informally-developed professional learning groups. Teaching and Teacher Education, 75(1), 302-315. https://doi.org/10.1016/j.tate.2018.07.008

Lave, J., \& Wenger, E. (1991). Situated learning: Legitimate peripheral participation. Cambridge: Cambridge University Press.

Lenihan, A. (2011). "Join our community of translators": Language ideologies and/in Facebook. In C. Thurlow \& K. Mroczek (Eds.), Digital discourse (pp. 48-64). New York: Oxford University Press. https://doi.org/10.1093/acprof:oso/9780199795437.003.0003

Manca, S., \& Ranieri, M. (2013). Is it a tool suitable for learning? A critical review of the literature on Facebook as a technology-enhanced learning environment. Journal of Computer Assisted Learning, 29(6), 487504. https://doi.org/10.1111/jcal.12007

Manca, S., \& Ranieri, M. (2017). Implications of social network sites for teaching and learning. Where we are and where we want to go. Education and Information Technologies, 22(2), 605-622. https://doi.org/10.1007/s10639-015-9429-x 
Miller, D., Costa, E., Haynes, N., McDonald, T., Nicolescu, R., Sinanan, J., Spyer, J., Venkatraman, S., \& Wang, X. (2016). How the world changed social media. London: UCL Press.

Nonnecke, B. \& Preece, J. (2000). Lurker demographics: Counting the silent. Proceedings of CHI 2000. The Hague: ACM. https://doi.org/10.1145/332040.332409

Özdemir, E. (2017). Promoting EFL learners' intercultural communication effectiveness: a focus on Facebook. Computer Assisted Language Learning, 6, 510-528. https://doi.org/10.1080/09588221.2017.1325907

Öztürk, E. (2015). Facebook as a new community of inquiry environment: An investigation in terms of academic achievement and motivation. Journal of Baltic Science Education, 14(1), 20-33. Retrieved from http://www.scientiasocialis.lt/jbse/files/pdf/vol14/20-33.Ozturk_JBSE_Vol.14_No.1.pdf

Patahuddin, S. M., \& Logan, T. (2019). Facebook as a mechanism for informal teacher professional learning in Indonesia. Teacher Development, 23(1), 101-120. https://doi.org/10.1080/13664530.2018.1524787

Peeters, W., \& Pretorius, M. (2020). Facebook or fail-book: Exploring "community" in a virtual community of practice. ReCALL, 32(3), 291-306. https://doi.org/10.1017/S0958344020000099

Peña-Ayala A. (2020). Educational networking: A novel discipline for improved learning based on social networks. Cham, Switzerland: Springer. https://doi.org/10.1007/978-3-030-29973-6

Perryman, L.-A., \& Coughlan, T. (2014). When two worlds don't collide: Can social curation address the marginalisation of open educational practices and resources from outside academia? Journal of Interactive Media in Education, 2014(2), Art. 3. https://doi.org/10.5334/jime.ab

Prenger, R., Poortman, C. L., \& Handelzalts, A. (2019). The effects of networked professional learning communities. Journal of Teacher Education, 70(5), 441-452. https://doi.org/10.1177/0022487117753574

Ranieri, M., Manca, S. \& Fini, A. (2012). Why (and how) do teachers engage in social networks? An exploratory study of professional use of Facebook and its implications for lifelong learning. British Journal of Educational Technology, 43(5), 754-769. https://doi.org/10.1111/j.1467-8535.2012.01356.x

Reinhardt, J. (2019). Metaphors for social media-enhanced foreign language teaching and learning. Foreign Language Annals, 53(2), 234-242. https://doi.org/10.1111/flan.12462

Rheingold, H. (2012). Net smart. Cambridge, MA: MIT Press.

Rodríguez-Hoyos, C., Haya, I \& Fernández-Diáz, E. (2015). Research on SNS and education: The state of the art and its challenges. Australasian Journal of Educational Technology, 31(1), 100-111. https://doi.org/10.14742/ajet.995

Rutherford, C. (2010). Facebook as a source of informal teacher professional development. In education, 16(1), 60-74. Retrieved from https://journals.uregina.ca/ineducation/article/view/76/512

Selwyn, N. \& Stirling, E. (2016). Social media and education ... now the dust has settled. Learning, Media and Technology, 41(1), 1-5. https://doi.org/10.4324/9781315121697-intro

Statista (2021a). Distribution of Facebook users worldwide as of January 2021, by age and gender. https://www.statista.com/statistics/376128/facebook-global-user-age-distribution/

Statista (2021b). Distribution of Facebook users in Turkey as of January 2021, by age of users. https://www.statista.com/statistics/1030023/facebook-users-turkey/ 
Staudt, D., St. Clair, N., \& Martinez, E. E. (2013). Using Facebook to support novice teachers. The New Educator, 9, 152-163. https://doi.org/10.1080/1547688x.2013.778764

Sumuer, E., Esfer, S. \& Yıldırım, S. (2014). Teachers' Facebook use: Their use habits, intensity, self-disclosure, privacy settings, and activities on Facebook. Educational Studies, 40(5), 537-553. https://doi.org/10.1080/03055698.2014.952713

Tønnessen, L.G. (2019). Facebook as a tool for teacher collaboration: A study of how Norwegian ESL teachers participate and share knowledge on social networking sites (Unpublished master's thesis), Norwegian University of Science and Technology, Trondheim, Norway.

Veletsianos, G. (2016). Social media in academia. New York: Routledge.

Yıldırım, İ. (2019). Using Facebook groups to support teachers' professional development. Technology, Pedagogy and Education, 28(5), 589-609. https://doi.org/10.1080/1475939x.2019.1686714

Wenger, E. (2000). Communities of practice and social learning systems. Organization, 7(2), 225-246. https://doi.org/10.1177/135050840072002

\section{Genişletilmiş Özet}

\section{Amaç}

Sosyal ağ siteleri bağlamında bilimsel araştırmalarının yabancı dil öğretmenlerin gayrıresmi mesleki gelişimleri gibi keşfedilmemiş boyutlarını kapsayacak şekilde genişletilmesinin önemini vurgulayan Rodríguez-Hoyos, Haya ve Fernández-Diáz (2015) ile Manca ve Raineri'nin (2017) çağrılarına bir cevap olan bu çalışmanın temel amacı İngiliz dili öğretimi alanında görev yapmakta olan öğretmenler için kurulan Facebook gruplarının sistematik olarak incelenmesi ve analiz edilmesidir. Facebook gruplarının İngilizce öğretmenleri ve mesleki gelişimleri üzerindeki rolü, değeri ve etkisinin incelenmesi üzerine yerel bağlamda yapılan çalışmaların genel görünümü (Deniz (2016) ve Yıldırım, (2019) hariç olmak üzere) bizlere eksik ve parçalı bir resim ortaya koymaktadır. Bu gereksinim ve eksiklikten hareketle, mevcut çalışma Türkiye'deki İngilizce öğretmenleri için mesleki gelişim ağları olarak hizmet veren Facebook gruplarının sistematik bir analizini sağlayarak bu boşluğu doldurmayı ve şu araştırma sorularına cevap bulmayı amaçlamaktadır:

Türkiye'deki İngilizce öğretmenleri için kurulan Facebook grupları

(1) kendilerini nasıl konumlandırıyor?

(2) ne tür faaliyetlere ve etkileşimlere ev sahipliği yapıyor?

\section{Tasarım ve Yöntem}

Araştırma süreci, hedef sorulara yanıt vermesi muhtemel grupların tespitine yardımcı olacak çeşitli anahtar kelimeler (örn. "İngilizce Öğretmenleri”, “ELT Türkiye”, “İngilizce Türkiye”) kullanılarak yapılan ön ve ham aramalarla başlamış ve bu aşamada toplamda 164 grup tespit edilmiştir. Makro-seviye analiz sürecine dahil edilmiş 55 grup aşağıdaki kriterler göz önünde bulundurularak tespit edilmiştir: (1) uygunluk (bireysel üyeler, etkinlikler, kurumlar için kurulan, İngilizce öğretimi ile ilgili olup öğretmenler veya mesleki gelişim ile ilgili 
olmayan gruplar çalışmadan çıkartılmıştır), (2) iletişim dili (herhangi bir dil kriteri kullanılmamış olup, Türkçe veya İngilizce kullanan gruplar veri analiz sürecine dahil edilmiştir). Bu aşamadaki gruplar makro-seviye analize dahil edilmiştir. Mikro-seviye analize dahil edilecek odak grupların tespit edilebilmesi için şu kriterler gözetilmiştir: odak (gruplar aktif olarak görev yapmakta olan İngilizce öğretmenleri için kurulmuş olmalıdır), boyut (en büyük üye grubuna sahip gruplar olmalıdır), günlük/aylık etkinlikler (Facebook'taki en aktif platformlar olmalıdır), paylaşımların varlığı (metinsel, görsel-işitsel ve çok biçimli paylaşımlar bulunmalıdır). Mevcut araştırma, 2020 yılı Haziran ayı boyunca yapılan toplam 1,252 paylaşımın ve gruplar hakkında bilgilerin (örn. grup isimleri, boyutu, çeşidi, tanımı, ve grup profil fotoğrafı, gibi) açıklayıcı yorumlanması amacıyla ("lurking" veya "gizlenme" olarak da bilinen) katılımcı olmayan etkinlik yöntemiyle verilerin MS Excel dokümanında arşivlenerek sistematik bir şekilde toplanması üzerine inşa edilmiştir (Nonnecke \& Preece, 2000).

Türkiye'deki İngilizce öğretmenleri için kurulan Facebook gruplarından toplanan veriler, yinelemeli iki aşamalı tematik içerik analizi ile analiz edilmiştir (Krippendorf, 2018). Makro-seviye analiz, verilere kuş bakışı bir bakış içermekte (1) açıklayıcı veriler sunmaya (boyut gibi) ve (2) bu grupların duruşlarını tanımlarken yaptıkları seçimlerdeki belli başı kalıpları belirlemeye (örneğin, grup isimleri, açıklamaları ve grup profil fotoğrafları gibi) içerirken mikro-düzeyde analiz, bu gruplara ve etkinlik örgülerine (gruptaki paylaşımlara) daha yakından baktı. Bu çalışma, kapsamı gereği etik kurul onayı gerektirmemektedir.

\section{Bulgular}

Araştırmanın bulguları aşağıda listelenmiştir:

- Çalışma kapsamında incelenen grupların büyük bir çoğunluğu kendilerini "paylaşım platformu" olarak konumlandırmıştır.

- Manca ve Rainieri’nin (2013) tiplendirmesi kullanıldığında grupların \%40’ını gene gruplar oluştururken büyük çoğunluğunu (\%60) özel amaçlar için kurulan gruplar oluşturmaktadır (örn. İngilizce Öğretmenleri için Materyal Değişim Grubu)

- Facebook’un “Hakkında” özelliğini kullanarak kendilerini tanımlayan grupların büyük bir çoğunluğu

○ bunu Türkçe yapmış,

○ kendilerini İngilizce öğretmenleri için ders materyali, dokümanı, haberler, etkinlik, kaynak ve fikir alışverişinde bulunabileceği alanlar veya platformlar olarak konumlandırmış,

○ yaptıkları tanımda "topluluk" kavramına atıf yapmıştır.

- Facebook'un "profil fotoğrafı" özelliğini kullanarak kendilerini tanımlayan grupların büyük bir çoğunluğu metinsel-görsel öğeler kullanarak

○ “topluluk" kavramına atıf yapmış,

○ kendilerini yerel bağlamda konumlandırmıştır.

- Odak gruplarda yapılan paylaşımlar incelediğinde

○ iletişim biçiminin tek yönlü olduğu,

- paylaşımların biçimsel çeşitlilik gösterdiği (yalnızca metinsel, metin + görsel, metin + bağlantı, yalnızca görsel, vs.), 
- grup üye sayısı ile paylaşım etkinliği (beğenme ve yorumlama) arasında doğru bir orantı olmadiğı,

○ en belirgin paylaşım temalarının sosyal (eğlence odaklı görsel-işitsel ve videolar, topluluk olgusunu oluşturmaya yönelik paylaşımlar, sosyopolitik konularda paylaşımlar, nostaljik paylaşımlar), idari (özellikle devlet okulu öğretmenlerine has süreçler, platformlar, belgeler, kurallar ve yönetmeliklerle ilgili sorular-sorunlar), ve ölçme-değerlendirme odaklı (değerlendirme testleri, çevrimiçi sınavlar, standartlaştırılmış testlerle ilgili güncellemelerduyurular, bir test sorusu için dışarıdan yardım arama) olduğu anlaşılmıştır.

İngilizce öğretmeni olarak görev yapan bireyler için kurulan Facebook gruplarının sistematik olarak incelenmesi neticesinde bu grupların aynı uzmanlık alanından gelen öğretmenleri bir araya getiren bu grupların faydacı (çoğunlukla bilgi veya öğretim videoları, revizyon testleri gibi dokümanlar isteme/paylaşma) ve sosyal merkezli (aynı mesleki temele gündelik gerçekliğe sahip meslektaşlar arasında yapılan sosyal paylaşımlar) olarak tanımlanabileceğini göstermektedir. Bu nedenle, bu grupların, (aynı uzmanlık alanından gelen) öğretmenleri bir araya getiren profesyonel odaklı sosyalleşme alanları ve aynı zamanda mesleki, idari, lojistik ve idari konularda etkileşime girdikleri, tartışma ve paylaşımlar yaptıkları dijital zümre odaları gibi hizmet ettiği sonucuna varılabilir.

\section{Sınırlılıklar}

Çalışmanın en temel sınırlılığı araştırma sürecinin 1 ay ile sınırlı olmuş olmasıdır. Her ne kadar çalışmanın temel bulguları konusunda net fikirler vermiş olsa da gelecekte yapılacak çalışmaların daha uzun soluklu yapılması verilerin derinleştirilmesi ve yapılacak çıkarımların sağlamlı̆̆ı açısından çok daha uygun olacaktır. Ek olarak, çalışmanın kurgusu itibariyle gözleme dayalı bir süreç izlenmiş ve bu gruplarda kurucu, yönetici, üye, paylaşımcı olarak farklı kimliklere sahip olan bireyler ile temas edilmemiştir. Gelecekte yapılacak çalışmaların bu açı̆̆ı kapatacağı kanısındayım.

\section{Öneriler (Teorik, Uygulama ve Sosyal)}

Mevcut araştırmanın sonuçlarından hareketle bu alanda yakın gelecekte atılacak adımlar birkaç noktaya odaklanabilir. Birincisi, Facebook gruplarının (veya benzeri dijital alanların) İngilizce öğretmenlerinin bireysel ve mesleki iyi halleri üzerindeki etkisi hakkında çalışmaların gerek niceliksel, gerekse de niteliksel olarak artması gerekmektedir. İkincisi, İngilizce öğretmenleri için kurulan Facebook gruplarındaki katılımcılar ile grup etkinlikleri arasında doğru bir oran olmaması ve dolayısıyla grup üyelerinin büyük bir çoğunluğu grup etkileşimlerinde görünür veya aktif olmaması bu çevrimiçi topluluklarda "katılım" ve "topluluk" kavramlarının yakın mercek altına alınması gerekliliğini de beraberinde getirmektedir. Son olarak, COVID-19 pandemisi ile değişen ve dönüşen dünyada öğrenme, öğretme ve mesleki gelişim hakkında yeni yollar, roller, alanlar düşünmek ve geliştirmek, eğitim kurumları, öğretmen yetiştirme programları ve eğitim sistemlerinin gündeminde yüksek bir önceliğe sahip olmalıdır. Bu noktadan hareketle, çevrimiçi dünya beraberinde geleneksel yöntemlere ek olarak daha esnek, becerikli, dirençli ve duyarlı olmamızı gerektirir. 


\section{Özgün Değer}

Çalışmanın özgün değeri birkaç noktada özetlenebilir. Birincisi, uluslararası bağlamda sosyal ağ platformları üzerine yapılan çalışmalarda keşfedilmemiş boyutları kapsayacak şekilde genişletilmesinin önemini vurgulayan çağrılara bir cevap nitelikte olmasıdır. Bununla bağlantılı olarak, yerel bağlamda sosyal medyanın bir alan ve araç olarak öğretmenlerin mesleki gelişimleri ve iyi halleri üzerindeki rolü, değeri ve etkisinin ortaya çıkmakta olan araştırmalara anlamlı bir katkı yapmasıdır. Dahası, dijital zümre odaları gibi hizmet eden bu gruplar özellikle COVID-19 pandemisi ile değişen ve dönüssen dünyada öğrenme ve öğretme süreçlerine ek olarak mesleki gelişim hakkında yeni yollar, roller, alanlar düşünme ve geliştirme konusunda karar vericilere bir çağrı niteliğindedir.

Araştırmacı Katkısı: Ali Fuad SELVİ (\%100). 